and heat in a vulcaniser which by the end of the process produced a hard, accurately fitting denture base to which porcelain teeth were then attached with metal pins. To further improve retention rubber suction pads were often incorporated into the palatal fitting surface and by the 1880s had superseded the necessity of springs which had been used 'successfully' for over 100 years.

Unfortunately the brownish colour of vulcanite was aesthetically unacceptable. To improve the appearance, thin slithers of porcelain were attached to the labial surface of the denture to mimic the colour and texture of healthy gum. However, vulcanite, though a great improvement over ivory, was brittle and, unlike ivory, prone to fracture. A broken denture could mean a soldier was unfit for active service. To be combatready a recruit had to have at least six pairs of functioning teeth, whether natural or artificial. To stop the breakages and the loss of troops from the front line aluminium dentures were introduced. They were first exhibited at the Baltimore Dental Meeting of 1866 by the American dentist Dr James Baxter Bean. The technique was revived and improved in 1917 by two American dentists while at the Presbyterian Base Hospital Unit, British Expeditionary Forces in France. They perfected the technique of making a complete full aluminium denture, including the teeth, from one casting. The design became known as 'Amex' dentures after the AMerican EXpeditionary force. The dentures were cheap to manufacture, lightweight, easily cleaned and almost indestructible - but very ugly. No one wanted a metal smile! Relatively few were made and at the end of the war production stopped.

All materials used in the mouth had proved inadequate in one way or another; even vulcanite became foul from bacterial growth over time and gold was the wrong colour. With the development of 'plastics' in the early twentieth century new materials became available for denture construction, but many like Bakelite, Celluloid and ICI Kellodent proved unsatisfactory. Following World War 2 acrylic resins came to the fore and have remained the material of choice for full dentures to this day.

So are dentures a necessity or just vanity? Well with the enormous amount of time and ingenuity spent by mankind to produce the perfect denture the answer must be...

The fascinating collection pictured here has been kindly donated to the BDA Museum by Dr Maurice Faigenblum in memory of Professor Arthur Chick, Head of Prosthetics at the Royal Dental Hospital.

BY BRIAN WILLIAMS, VOLUNTEER AT THE BDA MUSEUM AND RETIRED GENERAL DENTAL PRACTITIONER
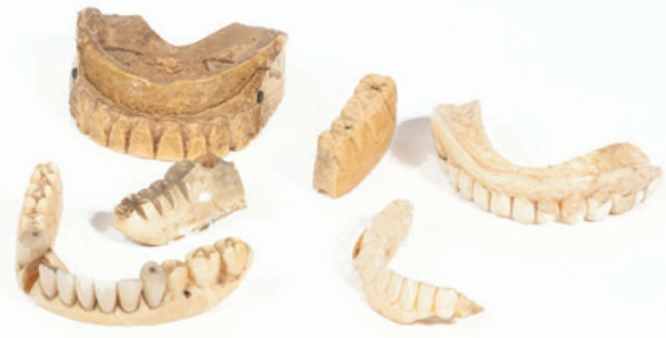

\section{GREATER MEASURES NEEDED TO TACKLE TOOTH DECAY}

Almost 26,000 children were admitted to hospital for tooth extractions in England in 20132014 and tooth decay is the most common cause of hospital admissions among 5-9-year-old children. The Faculty of Dental Surgery at the Royal College of Surgeons (RCS) has warned that action is needed to improve children's oral health.

A paper published in January by the Faculty, The state of children's oral health in England, ${ }^{1}$ highlights that tooth decay is almost entirely preventable and for the first time urges the Government, political parties and stakeholders to take greater measures to tackle the disease.

England lags behind Scotland and Wales in improving children's oral health. Between 2012 and 2014 the number of children who did not see an NHS dentist in England was double that of Scotland, where Governmentled initiatives such as Childsmile have been introduced to increase parental awareness of oral health.
Water fluoridation has also been shown to reduce the rate of tooth decay. In England, only $10 \%$ of the population benefit from a water supply where the fluoride content is at the optimum level for dental health. ${ }^{2}$

Currently the NHS spends £30 million on hospital-based tooth extractions for children so investing in preventative measures early on could mean long term savings for NHS Trusts.

1. Royal College of Surgeons of England. Faculty of Dental Surgery. The state of children's oral health in England. January 2015. Available at: http://www.rcseng. ac.uk/fds/policy/documents/fds-reporton-the-state-of-childrens-oral-health.

2. Public Health England. Delivering better oral health: an evidence-based toolkit for prevention (3rd ed). London, 2014. Available at: https://www.gov. uk/government/uploads/system/ uploads/attachment_data/file/367563/ DBOHv320140CTMainDocument_3.pdf.

\section{GLASGOW DENTISTS TREAT CHILDREN IN PALESTINE}

Four dentists from Glasgow have set up a dental charity called Dental Aid Network (DAN). The charity aims to arrange dental trips to impoverished areas of the world where access to dental treatment is difficult.

DAN was set up by Asid Khan, Attiq Rahman, Tariq Bashir and Omar Iqbal. In December they travelled to Palestine on their first trip, to provide preventive and simple restorative treatment and dental health education for children. The children were aged between five and 16-years-old, and many awre orphans or have special needs ranging from deafness to Down's syndrome and cerebral palsy.

The team travelled to the northern part of the West Bank in Palestine and worked from three dental clinics around the city of Nablus, using materials funded by donations from dentists and dental companies back home, and distriba Gaza refugee camp. www.dentalaidnetwork.org uting clothes and toys to children at

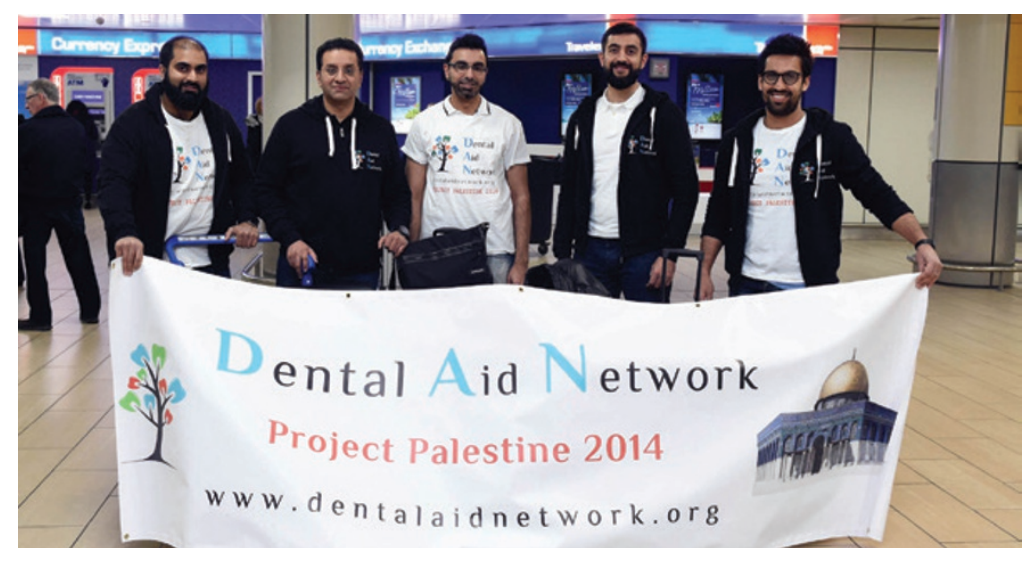

